\title{
Problematika Lembaga PAUD dalam Memenuhi Kebutuhan Tenaga Pendidik Sesuai Kualifikasi
}

\author{
Ali Iskandar Zulkarnain $\otimes_{1}$, Gito Supriadi 2 , Saudah ${ }^{3}$ \\ Pendidikan Islam Anak Usia Dini , Institut Agama Islam Negeri Palangaka Raya \\ DOI: $10.31004 /$ obsesi.v5i1.491
}

\begin{abstract}
Abstrak
Pendidik merupakan unsur penting dalam sebuah lembaga, Akan tetapi kenyataan yang terjadi saat ini, masih banyak tenaga pendidik di lembaga PAUD yang belum sarjana PAUD. Tujuan penelitian ini untuk menggambarkan keadaan dan kompetensi tenaga pendidik di PAUD dan mendiskripsikan problematika lembaga PAUD memenuhi tenaga pendidik sesuai kualifikasi. Penelitian ini menggunakan metode kualitatif dengan pendekatan deskriptif, adapun tehnik pengumpulan data menggunakan observasi, wawancara dan dokumentasi, analisis data menggunakan trianggulasi tehnik dan trianggulasi sumber. Hasil Penelitian menunjukan bahwa tenaga pendidik di lembaga PAUD kota Palangka Raya sudah terpenuhi, hal ini diketahui dari 30 lembaga terdapat 202 tenaga yaitu 48 orang SLTA, 141 orang S1 yang terdiri dari 20 orang S1 PAUD, 20 orang proses S1 PAUD, 15 orang S1 BK, 5 orang S1 Psikologi dan 81 orang tidak sesuai keahlian dan orang 3 orang S2. Adapun Problematika lembaga PAUD yakni masih kurangnya sumber daya manusia dan ketersediaan sumber dana dari lembaga PAUD.
\end{abstract}

Kata kunci: lembaga paud; tenaga pendidik; kualifiksi; paud.

\begin{abstract}
Educator is an important element in an institution, However, the reality that is happening now where many educators in PAUD institution that have not yet been PAUD Graduates. The purpose of this study is to describe the condition and the competence of educators in PAUD and to describe the problematics of PAUD institution in order to fulfill PAUD according to qualifications. This study uses a qualitative method with a descriptive approach, while data collection techniques use observation, interview and documentation, data analysis uses technical triangulation and source triangulation. The results showed that the teachers at PAUD institution in Palangka Raya had been fulfilled, it is known from 30 institutions that there were 202 educators that is 48 persons were SLTA, 141 persons were S1 which consisted of 20 persons were S1 PAUD, 20 persons are ongoing S1 PAUD, 20 persons were S1 BK, 5 persons were S1 Psychology and 81 not according to expertise and 3 persons were S2. For as problematic of PAUD is the lack of human resources and the availability of financial resources from PAUD.
\end{abstract}

Keywords: institution; educator; qualifications; early childhood education programs.

Copyright (c) 2020 Ali Iskandar Zulkarnain, Gito Supriadi, Saudah

$\triangle$ Corresponding author:

Email Address : andaiiskandar@gmail.com (Palangka Raya, Indonesia)

Received 5 March 2020, Accepted 18 April 2020, Published 21 April 2020 


\section{PENDAHULUAN}

Penyelenggaraan PAUD di Indonsesia saat ini mengalami perkembangan yang sangat signifikan hal tersebut terbukti dari banyaknya jenis layanan yang diberikan kepada anak berdasarkan usia dan karekteristik anak. Program layanan terbagi menjadi empat yaitu dalam bentuk Taman Kanak-kanak (TK)/Raudatul Athfal (RA)/Bustanul Athfal (BA), Kelompok Bermain (KB), Taman Penitipan Anak (TPA), dan Satuan PAUD Sejenis (SPS). diselenggarakannya pendidikan bagi anak usia ini bertujuan untuk memeberikan layanan untuk mendukung proses tumbuh kembang anak. Selanjutnya Pendidikan Anak Usia Dini adalah upaya pembinaan yang ditujukan kepada anak sejak lahir sampai usia 6 (enam) tahun yang dilakukan melalui pemberian rancangan pendidikan untuk membantu pertumbuhan dan perkembangan jasmani dan rohani agar anak memiliki kesiapan dalam memasuki pendidikan lebih lanjut. (Permendikbud No 137 Tahun 2014). Pada dasarnya Anak usia 3-5 tahun belum dapat mengerti dan menyadari akan pentingnya mengoptimalkan pertumbuhan dan perkembangan kecerdasannya karena keterbatasan tingkat berpikir dan pola pemahamannya. Oleh karena itu tidak hanya orang tua yang seharusnya memberikan asuhan atau pembelajaran kepada anaknya agar pertumbuhan dan perkembangan anaknya bisa optimal. Diperlukan ilmu pengetahuan dan wawasan yang luas serta keterampilan khusus dalam rangka lebih mengoptimalkan kecerdasan anak. Untuk itu peran Lembaga Pendidikan Anak Usia Dini (LPAUD) sangat penting dalam rangka mendidik anak agar masa usia keemasan (Golden Age) tidak sia-sia. Maka dari itu peran guru sangat penting untuk ditingkatkan profesionalismenya.(Suyanto, 2013)

Melihat Fenomena tersebut maka lembaga memiliki peran penting untuk menjamin kualitas pelayanan pendidikan yang sesuai dengan standar dan karakteristik anak dan mengacu pada tingkat pencapaian perkembangan anak yaitu perkembangan Nilai agama dan moral, fisik motorik, kognitif, bahasa, sosial emosional dan seni. Peran penting lembaga tidak terlepas dari peran tenaga pendidik yang telibat langsung dalam proses perencanaan, pelaksanaan dan evaluasi pembelajaran. Tenaga pendidik atau guru merupakan suatu profesi yang sangat mempengaruhi hasil belajar anak. (Zakiya, 2019). Oleh karena itu, tenaga pendidik yang mengajar di lembaga PAUD harus memenuhi standar dengan latar belakang pendidikan sesuai dengan bidang keahlian dan memiliki kompetensi sebagai guru PAUD.

Menurut Sutarmanto dalam (Saripudin, 2019) menyebutkan bahwa terdapat beberapa makna kompetensi guru PAUD, yaitu: (1) kemampuan untuk menguasai keahlian tertentu, sehingga dapat memberikan dampak dalam perkembangan anak usia dini. (2) kemampuan memberikan laporan pertanggungjawaban kepada stakeholder terhadap pembelajaran yang diberikan kepada anak. (3) Kompetensi sebagai pengetahuan, keterampilan, sikap dan nilai yang direfleksikan dalam kebiasaan berpikir dan bertindak. (4) Komptensi adalah spesifikasi dari pengetahuan, keterampilan dan sikap yang dimiliki seseorang dan mampu diterapkan dalam pekerjaan, sesuai dengan standar kinerja yang dibutuhkan di lapangan.

Saat ini pemerintah sangat memperhatikan terhadap pentingnya kompetensi bagi tenaga pendidik, karena harus kita sadari bersama bahwa guru memiliki peranan penting dalam mencetak generasi yang berkualitas, sebagaimana yang diungkapkan yufiarti dalam (Yuslam, 2017) bahwa terdapat tiga peran penting Guru PAUD, yaitu: (1) guru sebagai profesi penting dalam meningkatkan kualitas sumber daya manusia Indonesia. (2) Anak usia (0-6 tahun) atau pada masa golden age sangat memerlukan guru yang profesional, (3) guru yang profesional sangat didambakan untuk mempersiapkan sumber daya manusia yang berkualitas. Selain itu, pemerintah juga secara jelas menentukan syarat bagi tenaga pendidik atau guru PAUD dalam melaksanakan tugas keprofesiannya yaitu minimal memiliki kualifikasi S1 Sesuai bidang keahlian. Pemerintah juga telah mengatur hal tersebut melalui peraturan menteri yang menyatakan bahwa kualifikasi akademik guru PAUD minimal Memiliki ijazah Diploma empat (D-IV) atau Sarjana (S1) dalam bidang pendidikan anak usia dini, dan kependidikan lain yang relevan dengan sistem pendidikan anak usia dini, atau 
psikologi yang diperoleh dari program studi terakreditasi, dan Memiliki sertifikat Pendidikan Profesi Guru (PPG) PAUD dari perguruan tinggi yang terakreditasi. Adapun kompetensi guru PAUD dikembangkan secara utuh mencakup kompetensi pedagogik, kepribadian, sosial dan profesional. (Permendikbud No 137 Tahun 2014).

Menyikapi terbitnya standar kualifikasi dan profesi dari pemerintah, lembaga PAUD dalam hal ini pengelola PAUD mengambil sikap dan kebijakan yang berbeda-beda, karena setiap lembaga memiliki problematika masing-masinng untuk memenuhi tenaga pendidik yang sesuai dengan standar yang ditetapkan pemerintah. Pada dasarnya problematika yang dihadapi lembaga PAUD saat ini sangat bervariasi, akan tetapi setiap problematika yang dihadapi memiliki keterkaitan antara satu dengan lainnya. Sebagaimana pendapat Suyanto yang dikutip oleh (Saepudin, 2013) menyebutkan bahwa probelamtika penyelenggaraan PAUD mengarah pada enam hal yaitu: (1) Tingkat ekonomi yang lemah, (2) Kualitas asuhan rendah, (3) Program pelibatan orang tua yang rendah, (4) Kualitas PAUD yang rendah, (5) kuantitas PAUD yang kurang, (6) kualitas pendidik PAUD yang rendah. Dianatara probelmatika tersebut yang paling urgen adalah masalah kualitas pendidik PAUD yang masih rendah. Hal tersebut akan berpengaruh pula terhadap kualitas lembaga PAUD yang diselenggarakan.

Berdasarkan data awal yang diperoleh melalui observasi dan wawancara di lembaga PAUD didapatkan informasi bahwa terdapat beberapa lembaga yang menindak lanjuti peraturan tersebut dengan mengupayakan agar setiap guru harus memenuhi syarat sesuai standar dengan memberikan rekomendasi kepada guru yang beijazah SLTA dan guru yang berijazah S1 tidak sesuai bidang keahlianya untuk melanjutkan ke jenjang pendidikan S1 PAUD. Selain itu, terdapat pula lembaga PAUD atau tenaga pendidik yang tidak mampu untuk memenuhi standar yang ditetapkan pemerintah dengan alasan yang bervariasi, diantaranya, keterbatasan ekonomi, tidak ada sumber dana untuk melanjutkan pendidikan ke jenjang S1 PAUD. Hal tersebut selaras dengan data yang diperoleh dari Kantor Kementerian Agama Kota Palangka Raya terkait jumlah tenaga di lembaga PAUD khususnya guru Raudhatul Athfal yaitu 202 orang tenaga pendidik yang tersebar di 30 lembaga, akan tetapi dari keseluruhan jumlah tersebut hanya 20 orang guru yang berkualifikasi S1 PAUD dan 20 orang masih dalam proses kuliah diprogram PAUD.

Berdasarkan fenomena yang ditemukan, maka peneliti berkeinginan untuk melakukan penelitian tentang problematika lembaga PAUD memenuhi tenaga pendidik berkualifikasi S1 PAUD di Kota Palangka Raya. Penelitian ini akan menggambarkan tentang keadaan guru dan kompensi guru serta problematika lembaga PAUD dalam upaya memenuhi tenaga pendidik berkualifikasi S1 sesuai bidang keahlian di Kota Palangka Raya. Tujuan penelitian ini untuk menggambarkan keadaan dan jumlah tenaga pendidik serta kompetensi tenaga pendidik di PAUD dan mendiskripsikan problematika lembaga PAUD dalam memenuhi tenaga pendidik berkualifikasi S1 PAUD di kota Palangka Raya. Adapun manfaat yang diharapkan dari penelitian ini yakni agar dapat dijadikan bahan pertimbangan bagi lembaga dalam memenuhi tenaga pendidik di lembaga PAUD dengan mengacu pada kualifikasi dan kompetensi yang dimiliki oleh tenaga pendidik atau calon tenaga pendidik, selain itu juga dapat dijadikan bahan kajian bagi dinas terkait tentang penyediaan sumberdaya manusia dan serta pemenuhan pinansial bagi tenaga pendidik di lembaga PAUD.

\section{METODOLOGI}

Metode yang digunakan dalam penelitian ini adalah metode kualitatif pendekatan deskriptif artinya hasil dari penelitian ini disajikan dengan memaparkan data yang diperoleh dari hasil identifikasi tentang gambaran tenaga pendidik di lembaga PAUD se Kota Palangka Raya dan Problematika lembaga PAUD dalam memenuhi tenaga pendidik berkualifikasi S1 PAUD di lembaga PAUD se Kota Palangka Raya dengan mengambil objek penelitian sebagai 30 lembaga PAUD yang ada di Kota Palangka Raya. Tehnik pengumpulan 
data yang digunakan yaitu observasi, wawancara dan dokumentasi. alat yang digunakan berupa daftar ceklist, untuk mencek keberadaan tenaga pendidik dan kualifikasi pendidikan yang dimiliki tenaga pendidik, daftar wawancara dan dokumentasi berupa daftar jumlah guru dan kualifikasi pendidikan guru berdasarkan jenjang dan bidang keahlian.

Tehnik analisis data yang digunakan untuk menggambarkan tentang hasil penelitian dilakukan secara terstruktur menggunakan empat konsep cara yaitu pengumpulan data, reduksi data.(Miles\&Hubermen, 1992). Adapun Tehnik Pemeriksaan keabsahan data berdasarkan kereteria kepercayaan, maka yang digunakan adalah trianggulasi, yaitu tehnik pemeriksaan keabsahan data yang memanfaatkan sesuatu di luar data itu untuk keperluan pengecekan atau sebagai pembanding terhadap data itu.(Moleong, 2005). Triangulasi yang akan digunakan peneliti adalah triangulasi sumber yaitu membandingkan dan mengecek baik derajat kepercayaan suatu informasi yang diperoleh melalui alat yang berbeda. Hal ini dapat dicapai dengan cara: (1) membandingkan data hasil observasi dengan wawancara, (2) membandingkan subyek dan informan, (3) membandingkan hasil wawancara dengan dokumen yang berkaitan.

Berikut akan disajikan langkah penelitian tentang problematika lembaga PAUD dalam memenuhi tenaga pendidik berkualifikasi S1 PAUD di kota Palangka Raya

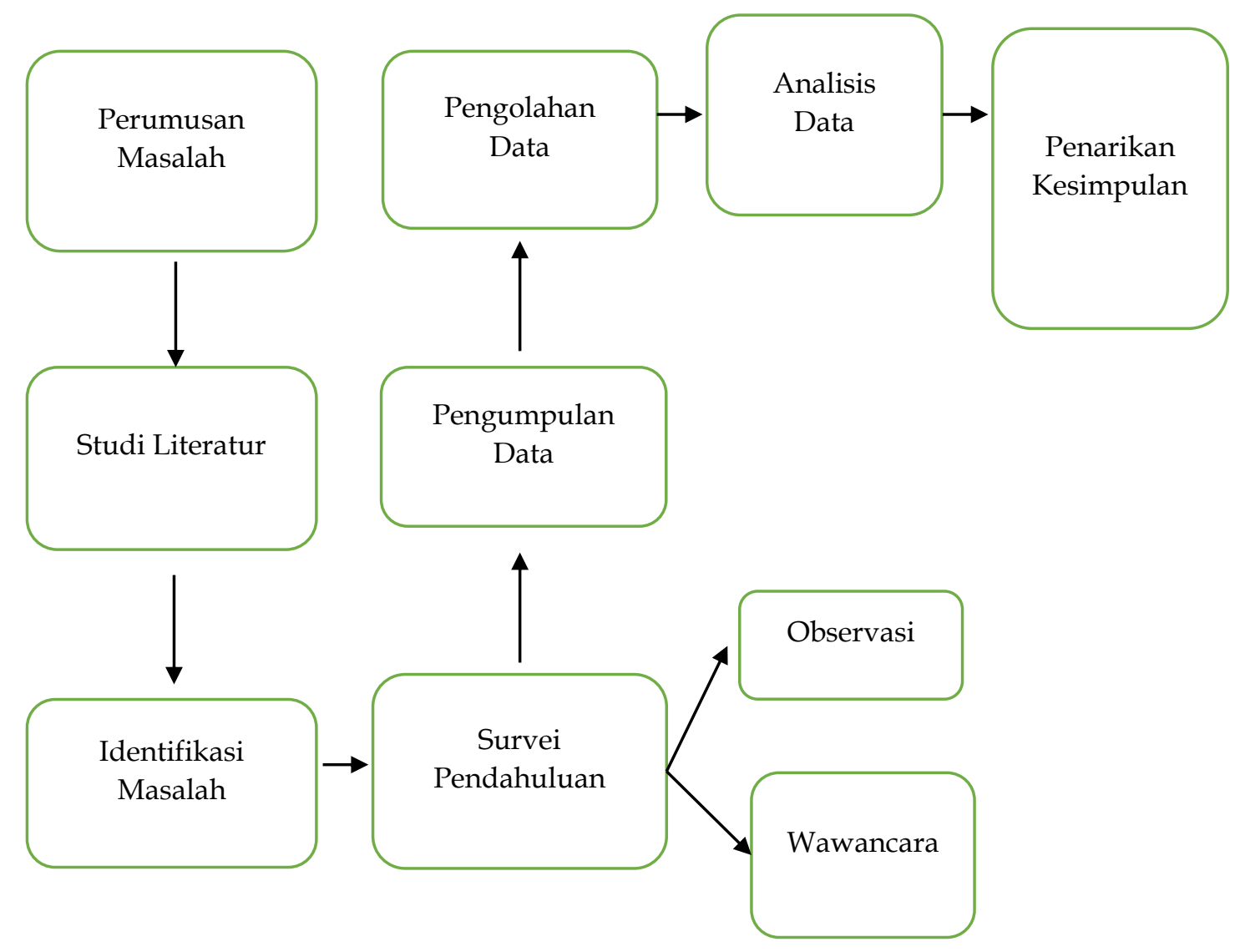

Gambar 1. Bagan Alur Penelitian

\section{HASIL DAN PEMBAHASAN}

\section{Gambaran Tenaga Pendidik PAUD di Kota Palangka Raya}

Gambaran tenaga pendidik PAUD di kota Palangka Raya, khususnya lembaga PAUD yang berada di bawah naungan Kementerian Agama Republik Indonesia yang berjumlah 30 lembaga PAUD. Adapun Rincian keadaan tenaga pendidik pada setiap satuan lembaga sebagai berikut: 
Tabel 1. Jumlah Guru dan Kulifikasi Pendidikan

\begin{tabular}{|c|c|c|c|c|c|c|c|}
\hline \multirow{2}{*}{ No } & \multirow{2}{*}{ Nama Lembaga Pendidikan } & \multicolumn{6}{|c|}{ Jumlah Guru dan Kualifikasi Pendidikan } \\
\hline & & SLTA & D1 & D2 & S1 & S2 & Jumlah \\
\hline 1 & RA Mutiara Insan & 1 & 0 & 0 & 2 & 0 & 3 \\
\hline 2 & RA Daruttaqwa & 3 & 0 & 0 & 2 & 0 & 5 \\
\hline 3 & RA Syaeful Islam & 2 & 0 & 0 & 2 & 0 & 4 \\
\hline 4 & RA Darussa'adah Pelatuk & 0 & 0 & 0 & 2 & 0 & 2 \\
\hline 5 & RA Hidayaturrahman & 2 & 0 & 0 & 5 & 0 & 7 \\
\hline 6 & RA At Taqwa & 0 & 0 & 0 & 2 & 0 & 2 \\
\hline 7 & RA Mawaddah & 5 & 0 & 0 & 2 & 0 & 7 \\
\hline 8 & RA Al Fattah & 3 & 0 & 0 & 6 & 0 & 9 \\
\hline 9 & RA Al Muslimun & 4 & 0 & 0 & 11 & 1 & 16 \\
\hline 10 & RA Amanah & 0 & 0 & 0 & 4 & 0 & 4 \\
\hline 11 & RA Darussa'adah Pinus & 2 & 0 & 0 & 11 & 0 & 13 \\
\hline 12 & RA Nurul Ikhwan & 2 & 0 & 0 & 7 & 0 & 9 \\
\hline 13 & RA Noor Al Banjari & 1 & 0 & 0 & 1 & 0 & 2 \\
\hline 14 & RA Nurul Hikmah & 1 & 0 & 0 & 9 & 0 & 10 \\
\hline 15 & RA Al Azhar & 1 & 0 & 0 & 8 & 1 & 10 \\
\hline 16 & RA Al Hunafa & 2 & 0 & 0 & 3 & 0 & 5 \\
\hline 17 & RA Al Muslihun & 3 & 0 & 0 & 4 & 0 & 7 \\
\hline 18 & RA Asmaul Husna & 2 & 0 & 0 & 4 & 0 & 6 \\
\hline 19 & RA Miftahul Jannah & 4 & 0 & 0 & 1 & 0 & 5 \\
\hline 20 & RA Al Husna & 0 & 0 & 0 & 5 & 1 & 6 \\
\hline 21 & RA Permata Hati Ibu & 0 & 0 & 0 & 3 & 0 & 3 \\
\hline 22 & RA Perwanida 2 & 1 & 0 & 0 & 12 & 0 & 13 \\
\hline 23 & RA Muslimat NU & 0 & 0 & 0 & 12 & 0 & 12 \\
\hline 24 & RA Al Musafirin & 7 & 0 & 0 & 1 & 0 & 8 \\
\hline 25 & RA Al Amin Banturung & 4 & 0 & 0 & 1 & 0 & 5 \\
\hline 26 & RA Hidayatul Insan & 3 & 0 & 0 & 5 & 0 & 8 \\
\hline 27 & RA Perwanida 1 & 4 & 0 & 1 & 11 & 0 & 16 \\
\hline 28 & RA Wardatul Musafirin & 0 & 0 & 0 & 2 & 0 & 2 \\
\hline 29 & RA Annisa & 2 & 0 & 0 & 2 & 0 & 4 \\
\hline \multirow[t]{2}{*}{30} & RA Al Mustaqim & 1 & 0 & 0 & 1 & 0 & 2 \\
\hline & Jumlah & 58 & 0 & 0 & 141 & 3 & 202 \\
\hline
\end{tabular}

Gambaran lembaga, jumlah guru dan kualifikasi pendidikan yang dimiliki guru pada masing-masing lembaga PAUD dapat di klasifikasikan berdasarkan jenjang pendidikan sebagai berikut: jumlah guru yang berkualifikasi pendidikan Sekolah Menengah Atas sebanyak 58 orang, D2 1 orang, S1 PAUD 20 orang, S2 3 orang, S1 Bimbingan konseling (BK) 15 orang, S1 Pskologi 5 orang, Proses kuliah 20 orang dan S1 diluar bidang keahlilan sebanyak 81 orang. Dari gambaran data yang diuraikan tersebut dapat disimpulkan bahwa jumlah tenaga pendidik pada masing-masing lembaga sudah terpenuhi, akan tetapi jumlah tenaga pendidik yang bekerja sesuai dengan bidang keahlian dan profesinya masih kurang, karena masih banyak tenaga pendidik yang belum memenuhi standar kualifikasi tenaga pendidik PAUD.

\section{Gambaran Kompetensi Tenaga Pendidik PAUD di Kota Palangka Raya Kompetensi Pedagogik}

Guru sebagai tenaga pendidik profesional bertugas untuk mendidik, mengajar, membimbing, mengarahkan, melatih, menilai, dan mengevaluasi peserta didik di PAUD jalur pendidikan formal, pendidikan dasar, dan pendidikan menengah. (Hamami, 2014). Untuk mendukung profesionalisme guru dalam melasksanakan tugsnya maka guru harus memiliki kompetensi, salah satu kompetendi yang harus dimiliki guru ialah kompetensi pedagogik. Kompetensi pedagogik merupakan kemampuan yang berhubungan dengan 
pengetahuan guru dalam melaksanakan tugasnya. Kompetensi pedagogik merupakan kemampuan untuk mengelola pembelajaran peseta didik yang meliputi pemahaman terhadap peserta didik, perancangan dan pelaksanaan pembelajaran serta pengevaluasi hasil belajar. (Supriadi, 2012).

Pemerintah melalui peraturan pendidikan dan kebudayaan No 137 tahun 2014 mengatur tentang indikator kompetensi pedagogik guru sebagai berikut: (1) Mampu engorganisasikan aspek perkembangan sesuai dengan karakteristik anak usia dini. (2) Mampu Menganalisis teori bermain sesuai aspek dan tahapan perkembangan, kebutuhan, potensi, bakat, dan minat anak usia dini. (3) Mampu merancang kegiatan pengembangan anak usia dini berdasarkan kurikulum. (4) Mampu menyelenggarakan kegiatan pengembangan yang mendidik. (5) Mampu memanfaatkan teknologi, informasi dan komunikasi untuk kepentingan penyelenggaraan kegiatan pengembangan yang mendidik. (6) Mampu mengembangkan potensi anak usia dini untuk pengaktualisasian diri. (7) Mampu Berkomunikasi secara efektif, empatik, dan santun. (8) Mampu menyelenggarakan dan membuat laporan penilaian, evaluasi proses dan hasil belajar anak usia dini. (9) Mampu Menentukan lingkup sasaran asesmen proses dan hasil pembelajaran pada anak usia dini. (10) Mampu menggunakan hasil penilaian, pengembangan dan evaluasi program untuk kepentingan pengembangan anak usia dini. (11) Mampu melakukan tindakan reflektif, korektif dan inovatif dalam meningkatkan kualitas proses dan hasil pengembangan anak usia dini.

Hasil observasi terhadap tenaga pendidik di lembaga PAUD menunjuka bahwa sebagian besar memiliki kopmetensi pedagogik yang dibuktikan dari kemampuan guru dalam memahami karaktristik anak, mengelola pembelajaran dan meningkatka mutu proses dan hasil pembelajaran. Hal tersebut diperkuat oleh pernyataan kepala sekolah yang menjelaskan bahwa secara umum saat ini tenaga pendidik sudah mampu dalam mengelola pembelajaran, akan tetapi semua melalui proses, apalagi guru yang tidak memiliki latar belakang sesuai bidang keahlian, mereka perlu dibimbing dan diarahkan agar dapat menyesuaikan dengan tenaga pendidik lainnya yang sebagian sudah memiliki kemampuan atau memiliki latar belakang pendidikan sesuai dengan bidangnya. Hasil dari dokumentasi berupa rancangan pembelajaran yang digunakan guru setiap hari sebagai panduan dalam melaksanakan pembelajaran membuktikan bahwa tenaga pendidik sudah mampu membuat rencana pembelajaran dan mempersiapkan alat dan bahan sebagai pendukung proses pembelajaran. Berdasarkan hal tersebut dapat disimpulkan bahwa secara umum tenaga pendidik di lembaga PAUD memiliki kompetensi pedagogik, akan tetapi pada prosesnya terbagi menjadi dau kategori yaitu: sebagian guru memiliki kompetensi sesuai dengan kemampuannya sebagai guru PAUD karena latar belakang pendidikan yang dimiliki sesuai dengan bidang keahlianny, sebagian guru yang lain memerlukan bimbingan dan arahan baik dari kepala sekolah maupun dari teman sebaya, karena latar belakang pendidikan yang dimiliki tidak sesuai dengan bidang keahlian dan sebagai besar pada jejang SLTA.

\section{Kompetensi Kepribadian}

Kompetensi kepribadian merupakan kemampuan yang berhubungan dengan sikap sebagai teladan bagi peserta didik. Kompetensi kepribadian menekankan kepada guru agar menjadi teladan (role model) bagi peserta didik, melakukan evaluasi diri dan mengembangkan diri secara berkelanjutan. (Momon, 2013). untuk menjadi role model guru juga harus memahami makna kesalehan yang terdapat dalam diri, sehingga dapat diikuti oleh peserta didik. Ruang lingkup kemampuan kepribadian mencakup tanggung jawab pribadi, sosial, inetelektual, moral dan spritual yang mana tanggung jawab pribadi dapat ditunjukan melalui kemampuan memahami dirinya, sedangkan tanggung jawab spritual dan moral diwujudkan melalui penampilan guru sebagai makhluk beragama yang berprilaku tidak menyimpang dari norma agama dan moral. (Suyanto, 2013). Pentingnya kompetensi kepribadian bagi guru, karena kepribadian guru tercermin dalam sikap dan 
perbuatan dalam membina dan membimbing peserta didik, dan dapat dijadikan sebagai profil dan idola agar menjadi sosok figur yang paripurna. (Anggraeni, 2017). Berdasarksan Permendikbud no 137 Tahun 2014 terdapat indikator kompetensi kepribadian guru PAUD sebagai berikut: (1) Bertindak sesuai dengan norma, agama, hukum, sosial, dan kebudayaan nasional Indonesia. (2) Menampilkan diri sebagai pribadi yang jujur, berakhlak mulia, dan teladan bagi anak usia dini dan masyarakat. (3) Menampilkan diri sebagai pribadi yang mantap, stabil, dewasa, arif, bijaksana, dan berwibawa (4) Menunjukkan etos kerja, tanggungjawab yang tinggi, rasa percaya diri, dan bangga menjadi guru. (5) Menjunjung tinggi kode etik guru.

Hasil observasi terhadap tenaga pendidik di lembaga PAUD terkait kemampuan kepribadian guru, menunjukan bahwa tenaga pendidik yang mengajar di lembaga PAUD di Kota Palangka Raya mampu menunukan kepribadian yang sesuai dengan standar guru PAUD hal tersebut dibuktikan dari cara berpakaian, bentuk tanggung jawab terhadap tugas dan memiliki sopan santun terhadap atasan, teman sebaya maupun peserta didik. Hal tersebut diperkuat oleh pernyataan kepala sekolah yang menjelaskan bahwa sejak awal yang kita lihat dari guru adalah kepribadiannya. Kompetensi kepribadian bagi guru PAUD itu sangat penting, karena guru tidak hanya mampu melaksanakan pembelajaran dengan baik, akan tetapi guru juga harus memberikan teladan yang baik kepada peserta didik, yang tercermin dari sikap, tingkah laku yang ditunjukan guru kepada peserta didik, maupun dengan sesama guru, kepala sekolah dan orang tua. Bagi saya secara umum rata-rata guru PAUD sudah memiliki kemampuan kepribadian, karena kita bisa menilai dari kesehariannya atau meilihat dari sesuatu yang nampak seperti sikap, cara berpakaian dan cara berkomunikasi. selain itu, guru juga mampu bertanggung jawab atas tugas yang diberikan dan mampu menjalin kedekatan kepada peserta didik. Berdasarkan hal tersebut dapat disimpulakan bahawa secara umum guru memliki kemampuan kepribadian yang sesuai dengan standara kompetensi guru, yang mengharuskan guru mampu bertanggung jawab terhdap tugas dan kewajiban, menunjukan sikap dan perilaku yang sesuai dengan norma, agama, hukum dan sosial.

\section{Kompetensi Profesional}

Kompetensi profesional sebagai salah satu gambaran kemapuan guru dalam melaksanakan tugas secara profesional. Kompetensi profesional yang harus dimiliki guru mencakup: kemampuan memahami dan menarapkan landasan pendidikan dan teori belajar, mampu mengembangkan keahlianya, mampu menerapkan metode pembelajaran yang bervariasi, mampu menggunakan alat, media dan sumber belajar, mampu melaksanakan program pembelajaran, mampu melaksanakan evaluasi pembelajaran dan mampu menumbuhkan kepribadian peserta didik. (Mulyasa, 2008). Berdasarksan Permendikbud no 137 Tahun 2014 terdapat indikator kompetensi profesioanl guru PAUD sebagai berikut: (1) Mengembangkan materi, struktur, dan konsep bidang keilmuan yang mendukung serta sejalan dengan kebutuhan dan tahapan perkembangan anak usia dini. (2) Merancang berbagai kegiatan pengembangan secara kreatif sesuai dengan tahapan perkembangan anak usia dini. (3) Mengembangkan keprofesionalan secara berkelanjutan dengan melakukan tindakan reflektif.

Hasil observasi di lembaga PAUD di Kota Palangka Raya menunjukan bahwa sebagian guru belum memiliki kemampuan profesional guru PAUD terlihat dari ketidakmampuan dalam mengembangkan diri sesuai bidang keahlian hal tersebut disebabkan latar belakang pendidikan yang dimiliki guru tidak sesuai dengan bidang keahlian. Adapun dari hasil wawancara dapat diketahui bahwa lembaga memiliki kendala dalam mengembangkan kompetensi profesional guru, hal tersebut disebabkan sebagian guru masih berjenjang pendidikan SLTA dan ada sebagian guru yang tidak berlatang belakang pendidikan S1 PAUD, hal tersebut membuat lembaga harus lebih aktif membimbing dan membina guru, agar mampu memenuhi indikator kemampuan rofesional 
guru. selain itu, hasil dokumentasi dari rekapitulasi guru berdasarkan jenjang pendidikan diketahui terdapat 48 orang guru yang berlatan belakang SMA dan 81 guru berlatang beakang S1 di luar PAUD. Berdasarkan hal itu, maka dapat disimpulkan bahwa gambaran kompetensi profesioanal tenaga Pendidik di lembaga PAUD kota Palangka Raya, sebagian belum memenuhi standar sebagai guru profesional karena masih terdapat guru yang berlatar belakang pendidikan yang tidak sesuai dengan bidang keahliannya.

\section{Kompetensi Sosial}

Menurut Weinert F. E., The concept of social competence defines personal behavior and expresses in a broad sense adaptive and effective functioning of a person in certain social situations. Usually a person's social competence is an expression of his/her interpersonal relationships and abilities to achieve targeted goals. In other words,social competence is the art of human expression which a person is learning during all his life, i.e. from an early age by his or her very existence and which reveals itself in human maturity, intelligence and awarenes.(Gedvilienè, 2012). Maksudnya kompetensi sosial merupakan perilaku seseorang untuk menjalankan fungsi adaptif secara efektif terhadap lingkungan, atau kemampuan dalam mengekspresikan diri untuk menjalin hubungan interpersonal dengan setiap individu.

Selain itu, Social competence was defined by Spence (2003, p. 84) as "the successful management of the social world (which) requires a sophisticated repertoire of social skills and in interpersonal problem solving capacity.(Michelle, 2012). Maksudnya adalah keberhasilan manajemen di dalam dunia sosial membutuhkan pemeran yang memiliki keterampilan sosial yang canggih dan dapat menyelesaikan atau memcahkan permasalahan antar individu. Selain itu, kompetensi sosial yang dimiliki oleh guru diartikan sebagai kemampuan tenaga pendidik atau guru yang merupakan bagian dari masyarakat dalam berkomunikasi dan bergaul secara efektif dengan peserta didik, tenaga kependidikan, orang tua/Wali peserta didik dan masyarakat sekitar.(Musfah, 2015).

Hasil Observasi menunjukan bahwa kemampuan tenaga pendidik di lembaga PAUD kota Palangka Raya, memiliki kemampuan sosial yang baik, hal tersebut dari kemampuan guru dalam menjalin komunikasi dengan peserta didi, teman sebaya, atasan dan orang tua/wali murid baik pada saat menyambut kedatangan anak, maupun pada saat menghantar anak saat pulang sekolah, selain itu, tenaga pendidik juga memiliki kepekaan sosial yang tinggi terhadap teman sebaya, jika mendapatkan permasalahan terkait pembelajaran. Adapun hasil wawancara diperoleh informasi bahwa tenaga pendidik di lembaga PAUD kota Palangka Raya secara keseluruhan mampu menunjukan kemampuan sosialnya, hal tersebut dapat dibuktikan dari kemampuan guru bersosialisasi baik dengan atasan, guru maupun orang tua. Berdasarkan hal tersebut dapat disimpulkan bahwa

\section{Problem Lembaga PAUD dalam Memenuhi Tenaga Pendidik Berkualifikasi S-1 PAUD Se Kota Palangka Raya \\ Ketersediaan Sumber Daya Manusia}

Guru atau tenaga pendidik pada suatu lembaga pendidikan adalah salah satu faktor penentu keberhasilan pendidikan, terlebih lagi pada lembaga PAUD, karena pada lembaga PAUD ini menangani anak usia 3-5 tahun yang belum dapat mengerti dan menyadari akan pentingnya mengoptimalkan pertumbuhan dan perkembangan kecerdasannya karena keterbatasan tingkat berpikir dan pola pemahamannya. Maka diperlukanlah seorang tenaga pendidik yang berlatar belakang pendidikan S1 PAUD guna menunjang keberhasilan pendidikan tersebut. Tidak semua lembaga PAUD memiliki guru yang berlatar belakang S1 Pendidikan PAUD. Data di lapangan didapat pada umumnya problem lembaga PAUD seKota Palangka Raya adalah (1) sebagian besar Guru yang ada pada lembaga PAUD belum memenuhi kualifikasi S1 PAUD, (2) Minimnya gaji guru PAUD sehingga mereka tidak mampu melanjutkan studinya ke S1 PAUD, (3) Menjadi Guru PAUD merupakan alternatif pekerjaan terakhir setelah pekerjaan lainnya tidak didapatkan. Agar tercipta SDM yang berkualitas pada milenium ketiga ini, maka pendidikan merupakan kebutuhan utama yang 
harus dipenuhi. pendidikan tersebut hendaknya diberikan sejak usia dini, karena pada usia dini perlu ditumbuh kembangkan kreatifitas anak. (Suharti, 2018).

Pertama, keberadaan guru pada lambaga PAUD di Kota Palangka Raya tidaklah kurang karena menggunakan tenaga pengajar seadanya. Seperti guru PAUD diambil dari lulusan SMA, atau S1 yang tidak sesuai dengan bidangnya, sehingga gugur kewajiban sekolah untuk mengadakan guru yang mengajar pada lembaga PAUD tersebut, dan lembaga PAUD tidak mewajibkan para gurunya harus S1 PAUD. Semestinya guru yang ada di lembaga PAUD itu adalah guru yang memiliki latar belakang pendidikan S1 PAUD sehingga dia bisa dikatakan sebagai pendidik yang profesional dalam bidang ke-AUD-an, hal ini disampaikan oleh Slamet Suyanto dalam Martha Christianti bahwa profesional berarti bekerja sesuai prosedur, mengikuti etika profesi dan ilmu PAUD, serta tidak melakukan kesalahan.(Christianti, 2012). Pendapat ini diperjelas oleh Driscoll bahwa "a profesional is someone who is educated, knowledgeable, dedicated to her profession, committed to completion of a specialized course of study, and in possesion of a knowladge base essential to her specialty area. (Driscoll, 2005)

Kompetensi pendidik PAUD dikembangkan dalam konteks kebijakan sesuai dengan standar Pendidikan Anak Usia Dini berdasarkan peraturan menteri pendidikan nasional RI no. 58 Tahun 2009. Berdasarkan acuan tersebut pendidik harus memiliki empat kompetensi yaitu kompetensi kepribadian, kompetensi profesional, kompetensi pedagogik, dan kompetensi sosial. Kompetensi kepribadian yaitu kemampuan untuk bersikap dan berperilaku sesuai dengan kebutuhan psikologis anak, sesuai dengan norma, agama, budaya dan keyakinan anak, dan menampilkan diri sebagai pribadi yang berbudi pekerti luhur. Pendidik yang memiliki kompetensi kepribadian ditunjukkan melalui tingkah laku yaitu menyayangi anak secara tulus, berperilaku sabar, tenang, ceria, serta penuh perhatian; memiliki kepekaan, responsif dan humoris terhadap perilaku anak; menampilkan diri sebagai pribadi yang dewasa, arif dan bijaksana; berpenampilan bersih, sehat dan rapi; berperilaku sopan santun, menghargai dan melindungi anak; menghargai anak tanpa membedakan keyakinan yang dianut, suku, budaya dan jender; bersikap sesuai dengan norma agama yang dianut, hukum dan norma sosial yang berlaku dalam masyarakat; mengembangkan sikap anak didik untuk menghargai agama dan budaya lain; berperilaku jujur; bertanggung jawab terhadap tugas; berperilaku sebagai teladan.

Kompetensi profesional terkait dengan kemampuan untuk memahami tahapan perkembangan anak, pertumbuhan dan perkembangan anak, kemampuan untuk memberikan rangsangan pendidikan, pengasuhan dan perlindungan, dan kemampuan untuk membangun kerjasama dengan orang tua dalam pendidikan, pengasuhan dan perlindungan anak. Kompetensi pedagogik adalah kemampuan yang terkait dengan merencanakan kegiatan program pendidikan, pengasuhan dan perlindungan, melaksanakan proses dan melaksanakan penilaian terhadap proses dan hasil pendidikan, pengasuhan, dan perlindungan. Kompetensi sosial adalah kemampuan guru dalam beradaptasi dengan lingkungan dan berkomunikasi secara efektif dengan anak didik, dan orang tua. Kompetensi ini ditunjukkan melalui kemampuan pendidik dalam menyesuaikan diri dengan teman sejawat; menaati aturan lembaga; menyesuaikan diri dengan masyarakat sekitar; akomodatif terhadap anak didik, orang tua, teman sejawat dari berbagai latar belakang budaya dan sosial ekonomi; berkomunikasi secara empatik dengan orang tua peserta didik; dan berkomunikasi secara efektif dengan anak didik, baik secara fisik, verbal dan nonverbal. (Christianti, 2012)

Kedua, ternyata kebanyakan Lembaga PAUD yang ada di Kota Palangka Raya menggaji gurunya sangat kurang memadai, bahkan dapat dikatakan kurang manusiawi. Banyak guru PAUD yang digaji jauh di bawah kebutuhan hidup minimal. Kondisi ini menyebabkan mutu guru PAUD bisa dikatakan rendah. Senada dengan pernyataan tersebut, menurut Paul Supeno yang dikutip oleh Tatan Zainal Mutakin menyatakan bahwa banyak guru kita masih rendah dalam kompetensi pengajaran, maka dalam pendidikan profesi dan 
sertifikasi kemampuan keterampilan mengajar harus diutamakan. (Mutakin, 2015) untuk meningkatkan kompetensi guru tersebut Lembaga PAUD yang memiliki guru-guru dengan latar belakang pendidikan SMA atau yang bukan S1 ke-AUD-an pada prinsipnya ingin melanjutkan kejenjang S1 PAUD sebagai bentuk pemenuhan kompetensinya sebagai guru yang mengajar di lembaga PAUD, akan tetapi karena kecilnya gaji yang mereka terima sehingga tidak memungkinkan mereka untuk melanjutkan ke jenjang S1 PAUD. Namun pihak lembaga PAUD tetap akan meningkatkan profesional guru yang latar belakang pendidikannya SMA atau S1 non ke-AUD-an dengan mengikutsertakan mereka dalam pelatihan dan workshop, baik yang diselenggarakan di tingkat regional maupun nasional yang diselenggarakan oleh Dinas Pendidikan dan Kementerian Agama serta perguruan tinggi yang mempunyai program studi Pendidikan Guru PAUD atau instansi yang terkait. Karena profesional guru sebagai sebuah profesi, maka menurut profesi adalah sebuah pekerjaan/jabatan yang memerlukan kemampuan intelektual khusus, yang diperoleh melalui kegiatan belajar dan pelatihan yang bertujuan untuk menguasai ketrampilan atau keahlian dalam melayani atau memberikan layanan pada orang lain. (Malawai, 2016)

Ketiga, ada keterpaksaan menjadi guru PAUD, karena mereka pada awalnya tidak memiliki pekerjaan tetap, dan berkeinginan mencari pengalaman mengajar sebagai batu loncatan untuk mencari pekerjaan lain atau mendaftar menjadi PNS. Namun ada juga yang memang bertahan sebagai guru karena sudah merasa dekat dengan anak-anak dan menjiwai pendidikan anak, berdasarkan hasil wawancara dengan kepala sekolah dan guru, bahwa mereka memiliki minat setelah mengajar, dan untuk meningkatkan kreatifitas para guru, maka perlu diberikan pemahan bahwa menjadi guru pada PAUD itu merupakan panggilan hati nurani, hal ini sebagaimana yang disampaikan oleh Ninik Yuliani: Menumbuhkan kreativitas guru TK dapat diawali dari menanamkan pemahaman bahwa menjadi guru merupakan panggilan hati nurani. Artinya menjadi guru harus didahului oleh adanya minat yang ada pada masing-masing (calon) guru. Kalau (calon) guru memiliki minat menjadi guru (bukan karena terpaksa) merupakan modal utama untuk mencapai tujuan pendidikan. Minat inilah yang kemudian diwujudkan dalam bentuk komitmen dan kecintaan mereka terhadap profesi guru. (Yuliani, 2013). Memang tidak mudah menanamkan minat tersebut kepada para guru, sehingga mereka beranggapan menjadi guru pada lembaga PAUD hanyalah sebagai batu loncatan. Hasil wawancara yang dilakukan dengan kepala PAUD, hampir semua kepala lembaga PAUD memberikan jawaban, bahwa para gurunya yang mengajar kebanyakan ingin menjadi PNS, dan mengajar di PAUD hanya sebagai batu loncatan sambil menunggu saat pendaftaran.

\section{Ketersediaan Sumber Dana}

Sumber Dana pendidikan atau pembiayaan pendidikan merupakan salah satu unsur penting dalam pengelolaan lembaga PAUD. Dana pendidikan merupakan seluruh pengeluaran yang berupa sumber daya (input) baik berupa barang maupun berupa uang yang ditujukan untuk menunjang kegiatan proses belajar mengajar (UU No 20 Tahun 2003). Mulyasa juga menyebutkan bahwa Keuangan dan pembiayaan merupakan salah satu sumber daya yang secara langsung menunjang efektivitas dan efisiensi pengelolaan pendidikan. (Mulyasa, 2002). Bahkan dengan kekurangan dana ini bias berakibat kepada penutupan lembaga PAUD, hal ini sebagaimana disampaiakan oleh Suharti .....banyaknya lembaga PAUD yang tutup diakibatkan oleh minimnya dana yang dimiliki oleh lembaga tersebut. (Suharti, 2018). Berdasarkan hal tersebut maka sumber dana atau pembiayaan pendidikan sangat menentukan proses pelaksanaan menajemen lembaga. sebagaimana yang dijelsakan oleh Nanang Fattah bahwa biaya pendidikan merupakan jumlah uang yang dihasilkan dan dibelanjakan untuk berbagai keperluan penyelenggaraan pendidikan yang mencakup gaji guru, peningkatan profesional peralatan, pengadaan alat-alat dan buku pelajaran, alat tulis kantor (ATK), kegiatan ekstrakulikuler, kegiatan pengelolaan pendidikan, dan supervisi pendidikan. (Mulyono, 2010) 
Ketersediaan sumber dana merupakan salah satu problematika yang dihadapi oleh sebagian lembaga PAUD di kota Palangka Raya pada saat ini. Sebagimana hasil wawancara yang menyatakan bahwa untuk menambah tenaga pendidik apalagi yang memiliki kualifikasi pendidikan yang sesuai bidang memerlukan pertimbangan bagi lembaga karena, beban dari pemenuhan standar tenaga pendidikan itu masih dibebankan kepada sekolah, sedangkan anggaran dana yang dimiliki sekolah masih minim. Sumber dana pasti yang dipergunakan sekolah untuk operasional sekolah berasal dari SPP dan bantuan BOP, dan dan BOP juga menyesuaikan dengan jumlah murid yang ada di sekolah dan hanya sekian persen saja yang dapat digunakan untuk gajih guru, selebihnya untuk biaya operasional peserta didik. Berdasarkan Hasil dokumentasi berupa RAPBS yang dimiliki sekolah dapat diketahui bahwa dana lembaga yang digunakan untuk gaji tenaga pendidik masih sangat minim, dan belum memenuhi standar minimun yang telah berlaku. Kalau dilihat dari pendanaan yang ada, maka untuk memiliki sebuah lembaga yang bermutu tentu akan sulit terwujud dan akan menjadi rumit. Hal ini seperti yang disampaiakan oleh Mukhibat bahwa Mutu pendidikan menjadi persoalan yang sangat rumit dan kompleks, baik yang berkaitan dengan perencanaan, pelaksanaan dan pelaporan pembiayaan pendidikan. Sementara kalau mengacu pada Standar PAUD alokasi pendanaan yang harus menjangkau bagi kegiatan yang berhubungan langsung dengan upaya peningkatan standar mutu PAUD. (Muhibat, 2020).

Berdasarkan hal tersebut dapat disimpulkan bahwa sumbar dana/pembiayaan pendidikan menjadi salah satu problematika lembaga PAUD untuk memenuhi tenaga pendidik bekualifikasi S1 PAUD dan mutu pendidikan PAUD, karena bertambahnya tenga pendidik secara otomatis akan manambah biaya pendidikan yang digunakan untuk gaji atau tunjangan guru/tenaga kependidikan dan operasional sekolah.

\section{SIMPULAN}

Gambaran jumlah guru yang berkualifikasi pendidikan Sekolah Menengah Atas sebanyak 58 orang, D2 1 orang, S1 PAUD 20 orang, S2 3 orang, S1 Bimbingan konseling (BK) 15 orang, S1 Pskologi 5 orang, Proses kuliah 20 orang dan S1 diluar bidang keahlilan sebanyak 81 orang. Dari gambaran data yang diuraikan tersebut dapat disimpulkan bahwa jumlah tenaga pendidik pada masing-masing lembaga sudah terpenuhi, akan tetapi jumlah tenaga pendidik yang bekerja sesuai dengan bidang keahlian dan profesinya masih kurang, karena masih banyak tenaga pendidik yang belum memenuhi standar kualifikasi tenaga pendidik PAUD. Dan Problematika lembaga PAUD di Kota Palangka Raya dalam memenuhi tenaga pendidik berkualifikasi S1 PAUD yakni masih kurangnya sumber daya manusia yang memiliki keahlian sebagai pendidik profesional di bidan ke-AUD-an, serta keterbatasan sumberdana dari lembaga PAUD se-Kota Palangka Raya

\section{UCAPAN TERIMAKASIH}

Kami sampaikan terima kasih kepada kepala Kantor Kementerian Agama Kota Palangka Raya yang telah mengijinkan penulis untuk melakukan penelitian serta memberikan data keberadaan PAUD di Kota Palangka Raya dan kepada para kepala PAUD dan pihak-pihak yang tidak biasa kami sebutkan satu persatu.

\section{DAFTAR PUSATAKA}

Anggraeni, D. A. (2017). Kompetensi Kepribadian Guru Membentuk Kemandirian Anak Usia Dini. AWLADY: Jurnal Pendidikan Anak, Vol.3(2), 28-48.

Christianti, M. (2012). Profesionalisme Pendidik Anak Usia Dini. Jurnal Pendidikan Anak, Vol.1(1).

Driscoll, A. dan N. dan N. G. (2005). Early Childhood Education, Birth-8. USA: Pearson Education. 
Gedvilienè, G. (2012). Social Competence of Teachers and Students The Case Study of Belgium and Lithuania. Genute Tedviliené. https://lib.ugent.be/catalog/ebk01:4100000004537896

Hamami, T. (2014). Mengembangkan Profesionalisme Guru: Konsep dan Implementasi Menjadi Guru Profesional. Yogyakarta: Suka Press.

Malawai, I. (2016). Peningkatan Kompetensi Guru dalam Rangka Mewujudkan Guru yang Profesional. Premiere Educandum, 1-15.

Michelle, D. B. (2012). Social Competence Education For Pre-Service Teachers. Presented to the Faculty of the Department of Child DevelopmentCalifornia State University, Sacramento. http://csusdspace.calstate.edu/bitstream/handle/10211.9/1843/Binder1.pdf?sequence=3

Miles\&Hubermen. (1992). Analisis Data Kualitatif. Jakarta: Universitas Indonesia.

Moleong, L. J. (2005). Metodologi Penelitian Kualitatif,. Bandung: Remaja Rosdakarya.

Momon, S. (2013). Profesi Guru: Dipuji, Dikritisi, dan Dicaci. Jakarta; PT. Raja Grafindo Persada.

Muhibat. (2020). Konstruksi Mutu Pendidikan Melalui Literasi Keuangan Pada Pendidikan Anak Usia Dini di Magetan. Jurnal Obsesi : Jurnal Pendidikan Anak Usia Dini, Volume 4 (2) 620-629

Mulyasa, E. (2002). Manajemen Berbasis Sekolah. Bandung: PT Remaja Rosdakarya.

Mulyasa, E. (2008). Standar Kompetensi dan Sertifikasi Guru. Bandung: Remaja Rosdakarya.

Mulyono. (2010). Konsep Pembiayaan Pendidikan. Yogyakarta: Ar-Ruzz Media Group.

Musfah, J. (2015). Redesain Pendidikan Guru (teori, Kebijakan, dan Prktik). (Jakarta: Prenadamedia group.

Mutakin, T. Z. (2015). Pengaruh Kompetensi, Kompensasi, dan Latar Belakang terhadap Kinerja Guru. Jurnal Formatif, 145-156

Saepudin, A. (2013). Problematika Pendidikan Anak Usia Dini Di Indonesia. Cakrawala Dini Pendidikan Anak Usia Dini, Volume 4(1), 1-15. https://ejournal.upi.edu/index.php/cakrawaladini/article/view/10371/6425

Saripudin, A. (2019). Kompetensi Guru Pendamping Paud Dalam Memenuhi Standar Layanan Paud Non Formal Di Kabupaten Tasikmalaya. AWLADY: Jurnal Pendidikan Anak, Vol.5(2), 63-78.

Suharti. (2018). Manajemen Pendidikan Anak Usia Dini (PAUD) dalam Rangka Meningkatkan Mutu Pembelajaran. Tadbir, 52-70.

Supriadi, D. dan D. D. D. (2012). Komunikasi Pembelajaran. Bandung: Remaja Rosdakarya.

Suyanto, dan A. J. (2013). Menjadi Guru Profesional. Jakarta: Esensi.

Suyanto, S. (2005). Konsep Dasar Pendidikan Anak Usia Dini. Jakarta: Depdiknas.

Yuliani, N. (2013). Minat pada Profesi Guru, Semangat Kerja dan Kreativitas Guru Taman Kanak-Kanak. Jurnal Psikologi, 633-654.

Yuslam, S. A. K. dan E. S. R. (2017). Studi Tentang Kompetensi Guru PAUD Berkualifikasi Akademik Sarjana PGPAUD Dan NonPG-PAUD di PAUD Istiqomah Sambas Purbalingga. Al-Athfal: Jurnal Pendidikan Anak, Vol.3(2), 151-168.

Zakiya, N. (2019). Pengembangan Keprofesian Berkelanjutan dalam Meningkatkan Profesionalisme Guru Pendidikan Anak Usia Dini. Jurnal Obsesi: Jurnal Pendidikan Anak Usia Dini, Volume 3(2), 356-365. https:/ / doi.org/10.31004/obsesi.v3i2.196 